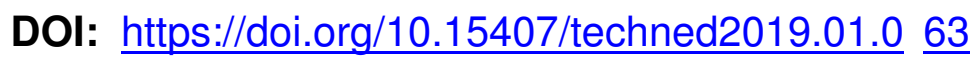

\title{
OVERVOLTAGES IN ELECTRIC NETWORKS OF OWN NEEDS OF POWER PLANTS DURING THE COMMUTATION OF VACUUM SWITCHES, AND THEIR LIMITATIONS
}

$\quad$ Journal
Publisher
ISSN
Issue
Pages

\section{Tekhnichna elektrodynamika} Institute of Electrodynamics National Academy of Science of Ukraine 1607-7970 (print), 2218-1903 (online)

No 1, 2019 (January/February)

$63-67$

\section{Authors}

\section{N.O. Ravlyk, O.M. Ravlyk, M.S. Seheda}

Lviv Natsional Polytechnik University,

str. S. Bandera, 12, Lviv, 79005, Ukraine,

Ravlyk.OM@gmail.com, mseheda@ukr.nete-mail: okjraa@gmail.com

\section{Abstract}

A mathematical model of the electrical network of own needs of power stations unit based on an asynchronous load and switching properties of the vacuum circuit breakers has been developed. Using computer simulation in a specialized digital complex "REC" investigated surge during switches of vacuum circuit breakers in the normal and emergency modes motors of own needs of power stations. References 10, figure 5 . 
Key words: own needs of power stations, asynchronous motors, vacuum switches, switching overvoltage, nonlinear overvoltage limiters, mathematical modeling.

Received: 14.11 .2016

Accepted: 04.10 .2018

Published: 10.01 .2019

\section{References}

1. Bazavluk A.A., Sarin L.I., Mikhailovskyi H.H., Naumkin I.E., Hoholiuk V.V. Surges due to switching of vacuum circuit breakers. Energoekspert. 2011. No 2. Pp. 27 - 32. (Rus)

2. Kuzmin S.V., Gavrilova E.V., Baryshnikov D.V. Effect of arc suppression process in the high-voltage circuit breakers on the value of switching surges that occur in networks $6-10 \mathrm{kV}$ mining. Gornoe oborudovanie i elektromekhanika. 2009. No 2. Pp. 41 - 44. (Rus)

3. Kyrylenko O.V., Levitskiy V.G. Fundamentals of automation of processes of calculating the electrical circuits. Kiev: Naukova Dumka, 2004. 242 p. (Rus)

4. Ravlyk O.M., Ravlyk N.O. Program complex «REC» to analyze processes in electrical networks, their protection and automation. Certificate of Registration of Copyright. No 62351. 2015. (Rus)

5. Ravlyk O.M. Methods for solving integral-differential equations finite transients of electrical. Visnyk Nastionalnoho Universytetu Lvivska Politekhnika. Elektroenerhetychni ta elektromekhanichni systemy

. 2005. No 544. Pp. 122 - 126. (Ukr)

6. Seheda M.S., Ravlyk N.O. Limitations of Internal surge in electric networks of own needs power when the single-phase earth fault. Naukovyi Visnyk Natsionalnoho hirnychoho Universytetu . 2014. No 6. Pp. 116 - 119. (Ukr)

7. Kulikovskii V.S., Kovalova O.A. Simulation of switching surges when switching high-voltage vacuum circuit breakers, motors. Vestnik KrasGAU. Energoobespechenie i energotekhnologii. 2012. No 5. Pp. 337 - 343. (Rus)

8. Ryudenberg R. Transients in power systems. Moskva: Izdatelstvo inostrannoi literatury, 1955. 714 p. (Rus)

9. Akash M. Patil, W.Z. Gandhare. Switching Surge Study on High Voltage Efficient Motor. Inte 
rnational Journal of Engineering Science and Innovative Technology (IJESIT). 2015. Vol. 4. Issue 3. Pp. 150-155.

10. C.Vollet, B.de Metz Noblat. Protecting High-Voltage Motors Against Switching Overvoltages. $4^{\text {th }}$ European Conference on Electrical and Instrumentation Applications in the Petroleum \& Chemical Industry , PCIC. Paris. 13-15 June, 2007. Pp. 1-7.

PDF 